\title{
POLA WAHYU MEMANDU ILMU DALAM PENANAMAN AKIDAH AKHLAK GENERASI MILENIAL
}

\author{
Miftahul Fikri
}

UIN Sunan Gunung Djati Bandung

E-Mail: miftahulfikrisiwa@uinsgd.ac.id

\begin{tabular}{|c|c|c|}
\hline Received & Revised & Accepted \\
\hline 4 July 2019 & 2 Agustus 2019 & 20 Agustus 2019 \\
\hline
\end{tabular}

\section{THE REVELATION MODELLING TO COACH KNOWLEDGE IN INCULCATING FAITH AND MILLENIAL GENERATION MORALITY}

\begin{abstract}
The purpose of writing this article is to provide a picture of the pattern in the cultivation of moral principles based on revelation to guide knowledge for millennial generation. The writing method uses the Sufi approach to the upright pyramid. Findings related to morality are weak belief in God with forms of fellowship in God that are not felt, and findings related to morality there are cases of immorality and many other cases that illustrate the corruption. This article discusses the pattern of planting a moral faith based on revelation to be applied in daily life rather than only at the level of science. Millennials who are now entering the heyday are in the spotlight. The pattern that is used refers to the concept of the magnets of sustenance that is at an applicative and practical level. The pattern used by positivating thoughts, positiveness of feelings and positivation of motivation. Planting positive thoughts by training yourself to always think positively, positively respond to the facts that occur, keep away the suuzan, substituting negative words for positive. Planting positive feelings by training yourself to be grateful for all circumstances, accepting the reality, believing that the calamity that comes must be accompanied by great pleasure, multiply reading the Koran, and focus on worship of God. Positive inculcation of motivation by practicing refrains from actions that fall into the zones of lust that have negative energy, and trains oneself to do actions that fall into the zone of piety that has positive energy.
\end{abstract}

Keywords: Revelation Modelling, knowledge, and millenial generation morality. 


\begin{abstract}
Abstrak
Tujuan penulisan artikel ini untuk memberikan gambaran pola dalam penanaman akidah akhlak berlandaskan wahyu memandu ilmu bagi generasi milenial. Metode penulisan menggunakan pendekatan sufistik piramida tegak. Temuan terkait akidah akhlak adalah lemahnya keyakinan kepada Allah dengan wujud-wujud persekutuan pada Allah yang tidak terasa, dan temuan terkait akidah adalah terdapat kasus asusila dan banyak kasus lainnya yang menggambarkan rusaknya akhlak. Artikel ini membahas pola penanaman akidah akhlak berlandaskan wahyu untuk diterapkan dalam keseharian bukan hanya pada tataran ilmu. Generasi milenial yang saat ini mulai memasuki masa berjaya menjadi sorotan. Pola yang digunakan merujuk pada konsep magnet rezeki yang berada pada tataran aplikatif dan praktis. Pola yang digunakan dengan mempositifkan pikiran, mempositifkan perasaan dan mempositifkan motivasi. Penanaman positif pikiran dengan melatih diri untuk selalu berpikir positif, mempositifkan respons dari fakta yang terjadi, menjauhkan suuzan, mengganti kata negatif menjadi positif. Penanaman positif perasaan dengan melatih diri untuk bersyukur atas semua keadaan, menerima kenyataan, meyakini musibah yang datang pasti beriringan dengan nikmat yang besar, perbanyak membaca AlQuran, dan fokus beribadah kepada Allah. Penanaman positif motivasi dengan melatih menghindarkan diri dari perbuatan yang masuk dalam zona nafsu yang memiliki energi negatif, dan melatih diri melakukan perbuatan yang masuk dalam zona takwa yang memiliki energi positif.
\end{abstract}

Kata kunci: pola wahyu, ilmu pengetahuan, dan akhlak generasi milenial.

\title{
Pendahuluan
}

Akidah dan akhlak sebagai landasan utama kehidupan seorang muslim perlu didalami dan diterapkan secara serius. Sebelum berbagai disiplin ilmu diterapkan, menerapkan akidah dalam setiap individu harus dilakukan pertama kali. Sebelum Allah mengizinkan manusia lahir ke bumi, Allah langsung yang menanamkan nilai akidah dan manusia itu sendiri sudah bersaksi bahwa Allah adalah tuhan semesta alam dan tidak ada tuhan selain-Nya. Hal ini sesuai dengan ayat Al-Quran surah AlA'raf ayat 172: "Dan (ingatlah) ketika Tuhanmu mengeluarkan dari sulbi (tulang belakang) Anak-Cucu Adam keturunan mereka dan Allah mengambil kesaksian terhadap ruh mereka (seraya berfirman), "Bukankah Aku ini Tuhanmu?" Mereka menjawab, "Betul (Engkau Tuhan kami), kami bersaksi." (Kami lakukan yang demikian itu) agar di hari kiamat kamu tidak mengatakan, "Sesungguhnya ketika itu kami lengah terhadap ini" ${ }^{1}$.

Dua tahun pertama manusia dilahirkan nilai pertama yang perlu ditanamkan adalah nilai akidah, dan mengoneksikan antara kesaksiannya di dalam alam kandungan atau alam sebelum dilahirkan dengan alam setelah dilahirkan yaitu di dunia. Ini dilandaskan pada hasil penelitian Ani Nur Aeni yang menyatakan bahwa manusia dilahirkan ke dunia dalam kondisi fitrah, dan memiliki potensi tauhid, yaitu meyakini bahwa Allah maha Esa dan berusaha terus untuk mencari tauhid tersebut.

\footnotetext{
${ }^{1}$ Andi Subarkah et al., Syamil Quran, Al-Quran Dan Terjemah (Bandung: Syamil Quran, 2012).
} 
Bayi lahir sangat penting untuk memperdengarkan kalimat-kalimat tauhid ini dalam rangka tetap menjaga tauhidnya, sampai bayi menginjak usia 2 tahun sudah diberi kemampuan untuk berbicara, maka kata-kata yang akan keluar dari mulutnya adalah kata-kata tauhid/kalimat thayyibah sebagaimana yang sering diperdengarkan kepadanya ${ }^{2}$.

Akhlak adalah respons diri saat berada dalam suatu kondisi. Tingkah laku dan kepribadian diri merupakan bagian dari akhlak. Akhlak ada yang baik dan ada yang tidak baik. Akhlak seseorang dipengaruhi oleh internal dan eksternal diri. Ruhenda dan Dessi Anggraeni menyatakan bahwa akhlak adalah tingkah laku baik atau buruk yang melekat pada seseorang. Akhlak dapat menimbulkan perbuatan-perbuatan yang baik lagi terpuji oleh akal dan syara atau hukum Islam ${ }^{3}$. Hal ini menunjukkan bahwa internal individu agar dapat berakhlak perlu berlandaskan akidah yang kuat dan sudah ditanamkan sejak awal, serta perlu adanya faktor eksternal berupa lingkungan yang didesain berdasarkan wahyu (Al-Quran dan Hadits). Penanaman akhlak adalah bagian yang tidak kalah penting karena merupakan bagian dari pola mendesain lingkungan untuk menjadikan setiap individu dapat menjalankan aktivitas keagamaannya dengan baik. Seharusnya menanamkan akhlak yang baik perlu dilakukan sejak kecil, tetapi membentuk lingkungan yang berakhlak di semua tempat aktivitas merupakan keharusan bagi setiap muslim. Salah satu tempat aktivitas ini adalah lembaga pendidikan tinggi tempat seseorang menuntut ilmu. Yunus \& Dewi adalah salah satu peneliti yang ingin memperbaiki akhlak. Salah satu caranya menerapkan strategi bagi guru akidah akhlak dalam menanamkan karakter islami peserta didik di salah satu sekolah dengan memberikan nasihat dan motivasi, keteladanan, pembiasaan, penyampaian pembelajaran dengan metode ceramah, penugasan dan pemberian hukuman yang mendidik bagi peserta didik yang melanggar peraturan atau tata tertib di sekolah ${ }^{4}$.

Saat ini individu yang lahir di era milenial telah mulai memasuki masa menduduki posisi yang menggerakkan berbagai bidang. Generasi awal milenial (kelahiran 1980-1990an) sudah mulai memasuki berbagai bidang pekerjaan di antaranya Pegawai Negeri Sipil di bidang pendidikan yaitu Dosen. Generasi akhir milenial (kelahiran 1990-200oan) sudah mulai memasuki pendidikan tinggi dan menjadi mahasiswa. Dosen yang lahir di era milenial dan mahasiswa yang juga samasama berada pada generasi yang sama telah berada pada posisi yang tepat untuk saling berinteraksi. Generasi ini disebut oleh sebagian ahli berada pada masa postmodern dan sebagai masa yang mengembalikan zaman menuju pada spiritualitas. Hal ini disampaikan oleh Abuddin Nata yang menyatakan bahwa Era ini diartikan oleh sebagian pakar sebagai era back to spiritual and moral atau back to religion. Yaitu masa kembali kepada ajaran spiritual, moral dan agama. Era milenial ini muncul sebagai respon atas era modern yang lebih mendahulukan akal, empiris, dan hal-hal

\footnotetext{
${ }^{2}$ Ani Nur Aeni, “Pendidikan Karakter Untuk Siswa SD Dalam Perspektif Islam,” Mimbar Sekolah Dasar 1, no. 1 (2014): 57.

${ }^{3}$ Ruhenda and Dessi Anggraeni, "Penanaman Nilai Agama Islam Dalam Keluarga Dengan Akhlak Remaja," Jurnal Obor Penmas 1, no. 1 (2018): 36.

${ }^{4}$ Ummu Kalsum Yunus and Kurnia Dewi, "Streategi Guru Akidah Akhlak Dalam Menanamkan Karakter Islami Peserta Didik MTs. GUPPI Samata Gowa," Jurnal Isnfirasi Pendidikan VII, no. 1 (2018): 93.
} 
yang bersifat materialistik, sekularistik, hedonistik, fragmatik, dan transaksional. Yaitu pandangan yang memisahkan urusan dunia dengan urusan akhirat ${ }^{5}$. Generasi milenial harus membawa semangat perjuangan membawa kembali pada akidah yang kuat serta akhlak yang baik melalui sebuah disiplin ilmu yang terstruktur dan berlandaskan wahyu.

Semangat perjuangan generasi milenial yang akan membawa era menuju era yang penuh dengan spiritual dan moral harus menanamkan dan mengamalkan akidah dan akhlak yang kuat berlandaskan wahyu. Kondisi ini menunjukkan bahwa Wahyu Memandu Ilmu sangat urgen untuk diaplikasikan pada proses penanaman akidah dan akhlak di lembaga pendidikan tinggi. Universitas Islam Negeri Sunan Gunung Djati Bandung sebagai universitas Islam yang menerapkan konsep Wahyu Memandu Ilmu perlu lebih serius dalam penanaman ilmu akidah dan akhlak. Akidah yang menyandarkan bahwa Allah adalah Tuhan yang maha Esa sebagai landasan ontologis WMI, dan akhlak yang baik (Al-akhlak Al-karimah) buah dari iman, ilmu dan amal saleh sebagai landasan aksiologis WMI, serta ilmu akidah akhlak yang merupakan bagian dari disiplin ilmu sebagai landasan epistimologis WMI ${ }^{6}$ jika berhasil ditanamkan, akan membawa Universitas Islam Negeri Sunan Gunung Djati Bandung melahirkan ilmuan yang diharapkan.

Terdapat artikel terdahulu yang berkaitan dengan akidah akhlak. Artikel-artikel terdahulu tersebut dapat dijadikan sebagai rujukan dalam penulisan artikel ini. Di antaranya artikel yang ditulis Andewi, dapat disimpulkan bahwa pengembangan bidang ilmu Pendidikan Agama Islam yang terdiri dari tiga dimensi besar, yaitu aspek dasar ajaran Islam (wahyu dan alam), aspek pokok-pokok ajaran Islam (iman, Islam, dan ihsan), dan aspek pendidikan Islam (Sejarah Pendidikan Islam, Filsafat Pendidikan Islam, Ilmu Pendidikan Islam, Psikologi Pendidikan Islam, Sosiologi Pendidikan Islam, Antropologi Pendidikan Islam, Manajemen Pendidikan Islam) pada kerangka wahyu memandu ilmu, dilakukan dengan menggunakan pendekatan multidisipliner. Penerapan paradigma multidisipliner dalam mengkaji Pendidikan Agama Islam berarti bagaimana pendidikan Agama Islam dikaji oleh berbagai sudut pandang keilmuan tersebut. PAI merupakan bidang ilmu pokok yang menjadi satu komponen yang tidak dapat dipisahkan dengan bidang ilmu lain yang bertujuan untuk pengembangan moral dan kepribadian peserta didik. Semua bidang ilmu yang memiliki tujuan tersebut harus seiring dan sejalan dengan tujuan yang ingin dicapai oleh bidang ilmu PAI ${ }^{7}$. Artikel ini menjadi bagian dari strategi wahyu memandu ilmu yang diterapkan dalam disiplin ilmu Pendidikan Agama Islam secara umum.

Selain Andewi, artikel berikut juga dapat penulis jadikan referensi untuk untuk konsep WMI bagi pendidikan, tauhid dan akhlak. M Sobandi menyimpulkan bahwa

\footnotetext{
5 Abuddin Nata, "Pendidikan Islam Di Era Milenial," Conciencia 18, no. 1 (2018): 10, https://doi.org/https://doi.org/10.19109/conciencia.v18i1.2436.

${ }^{6}$ Tim Penyusun Konsorsium WMI, "Buku 1 Trilogi Wahyu Memandu Ilmu," in Trilogi Wahyu Memandu IImu (Bandung: Konsorsium Wahyu Memandu IImu, 2016), 14-15.

${ }^{7}$ Andewi Suhartini, "Strategi Penerapan Wahyu Memandu Ilmu Dalam Bidang Ilmu Pendidikan Agama Islam Di UIN Sunan Gunung Djati Bandung," in Buku 2 Trilogi Wahyu Memandu Ilmu (Bandung: Wahyu Memandu Ilmu, 2016), 95.
} 
WMI (Revelation Guide on Science) lebih santun dari istilah Islamization of Knowledge (al-Faruqi) yang berkonotasi menyerang (agresif). Islamisasi ilmu pengetahuan mengundang kritik dari Barat, maka muslim harus memikirkan metode baru dalam WMI sehingga menghasilkan ilmu teknologi yang mandiri, orisinal dan bercirikan penjunjung Tauhid. Metode idealis akan menghasilkan Ilmu Islam yang orisinal dan inovatif. WMI jangan hanya menghasilkan ilmu semata tetapi harus menghasilkan ilmu-teknologi yang aplikatif dan dapat menyejahterakan masyarakat/Ummat lahir batin. Untuk itu perubahan disiplin dan etos kerja harus menjadi fokus kajian WMI. Diperlukan training dan upgrading serta sosialisasi kepada sivitas akademika dan masyarakat di lingkungan dan di umum. Diperlukan penghargaan dan insentif yang lebih tinggi untuk pemikir WMI sebagaimana terjadi di zaman Abbasiyah. Di zaman itu telah diraih masa keemasan muslim (the golden Ages of Muslim) ${ }^{8}$. Sobandi menganggap bahwa istilah wahyu memandu ilmu adalah metode yang lebih santun untuk membawa nilai Islam kepada ilmu.

Tujuan penulisan artikel ini untuk menggambarkan pola secara umum dalam penanaman akidah akhlak berlandaskan wahyu memandu ilmu pada mahasiswa yang masuk kategori generasi milenial. Artikel ini lebih menekankan pada pola penanaman yang perlu mulai dilakukan demi terciptanya masyarakat ilmiah dilingkungan Universitas Islam Negeri Sunan Gunung Djati Bandung yang berakhlak karimah sesuai dengan harapan Wahyu Memandu Ilmu. Perbedaan pembahasan artikel ini dengan artikel lain adalah penerapan yang dilakukan kepada mahasiswa yang merupakan generasi milenial dan bahkan dalam rangka mempersiapkan masuknya mahasiswa dari generasi yang sudah berbeda lagi. Perbedaan generasi ini tentu akan membedakan pola penanamannya. Ali bin Abi Thalib berpesan, didiklah anak sesuai zamannya ${ }^{9}$.

\section{Temuan dan Pembahasan}

\section{Temuan}

Akidah yang diajarkan Islam adalah tauhidullah, yang bukan hanya mengetahui bahwa Allah itu Esa, tetapi memang meyakini dan menerapkan hasil dari keyakinannya. Mempelajari ilmu akidah ini adalah sesuatu yang sangat-sangat mudah, tetapi masalah menerapkannyalah yang sangat-sangat tidak mudah. Menerapkan akidah yang tidak tepat ini banyak menimbulkan permasalahan, dari masalah yang dianggap lumrah sampai benar-benar menodai agama. Kasus yang terjadi pada generasi milenial salah satunya adalah saat seleksi Calon Pegawai Negeri Sipil 2018, banyak ditemukan peserta yang membaca jimat saat melakukan ujian ${ }^{10}$. Ini memang kasus yang berada secara umum, dan berada di salah satu kota

\footnotetext{
${ }^{8}$ M Sobandi, "Wahyu Memandu IImu Dan Implementasinya Untuk Menggapai the Second Golden Ages of Muslim," in Buku 2 Trilogi Wahyu Memandu Ilmu (Bandung: Wahyu Memandu Ilmu, 2016), 158-59.

${ }^{9}$ Hadhari, "Tela'ah Atas Keteladanan Rasulullah Saw Dalam Mendidik Anak," Sumbula: Jurnal Studi Keagamaan, Sosial Dan Budaya 1, no. 1 (2016): 161.

${ }^{10}$ Sugeng Harianto, "Menggelikan, Puluhan Peserta Tes CPNS Di Madiun Ketahuan Bawa Jimat," Detik News (Madiun, November 2018).
} 
di luar Jawa Barat. Kasus ini adalah permasalahan yang mungkin dianggap sebagai masalah lumrah oleh sebagian orang, tetapi dalam tataran akidah, meyakini bahwa jimat mampu membuat lolos sebuah seleksi adalah sebuah kesirikan. Kesirikan ini adalah sebuah dosa besar yang sebenarnya sangat dengan nyata menentang Allah. Hal ini seolah-olah meyakini bahwa Allah tidak melakukan sesuatu sampai-sampai membutuhkan Tuhan lain bernama jimat. Allah berfirman dalam surah An-Nisa ayat 48:"Sesungguhnya Allah tidak akan mengampuni dosa syirik, dan Dia mengampuni segala dosa yang selain dari (syirik) itu, bagi siapa yang dikehendakiNya. Barang siapa yang mempersekutukan Allah, maka sungguh ia telah berbuat dosa yang besar" ${ }^{11}$.

Ayat ini menjelaskan bahwa Allah tidak main-main dengan dosa menyekutukan Allah ini. Dosa besar ini jika dibiarkan terus menerus akan membuat orang yang melakukannya berada dalam kesesatan dan jauh dari pertolongan Allah dan bahkan akan mendapatkan azab dunia dan akhirat. Permasalahan yang juga dialami oleh UIN Sunan Gunung Djati ini adalah salah satu catatan tidak baik dan sangat-sangat menodai. Mahasiswa yang berteriak lantang "Anjing hu-Akbar" di depan mahasiswa baru pada tahun 2004 ini adalah bagian dari permasalahan akidah. Mahasiswa ini mengatakan hal tersebut dianggap oleh wakil rektor UIN Sunan Gunung Djati Bandung bermula dari perbedaan pijakan berpikir ${ }^{12}$. Ini adalah bagian dari temuan-temuan masalah yang berkaitan dengan disiplin ilmu Akidah Akhlak.

Selain itu juga terdapat satu dari banyak permasalahan yang berkaitan dengan akhlak. Terdapat kejadian yang menyayat hati pendidikan Indonesia, dua bocah SD yang berciuman di sekolah dan disaksikan banyak temannya pada jam sekolah berlangsung, direkam oleh salah satu temannya dan videonya viral di media sosial. ${ }^{13}$. Kejadian ini terjadi di lembaga pendidikan formal dan di waktu belajar yang seharusnya siswa memang sedang belajar. Permasalahan lainnya yang terjadi di lingkungan UIN Sunan Gunung Djati Bandung pada Oktober 2018, seorang mahasiswa semester 5 sedang melakukan perbuatan asusila dengan mahasiswi baru dan terekam oleh serta viral di media sosial ${ }^{14}$. Kejadian ini terjadi di lembaga pendidikan tetapi berada pada jenjang yang berbeda. Lagi-lagi ini hanya satu temuan dari banyak kejadian yang menjadi permasalahan akhlak.

\section{Pembahasan}

Permasalahan berdasarkan temuan-temuan yang ada dapat dianalisis bahwa terdapat ketidaksesuaian antara akidah yang dimiliki dengan perilaku yang mencerminkan akhlak masing-masing individu. Ketidakyakinan seseorang terhadap

\footnotetext{
${ }^{11}$ Subarkah et al., Syamil Quran, Al-Quran Dan Terjemah.

${ }^{12}$ Haikal, "Komentar IAIN/UIN Tentang Dzikir Anjing-Hu Akbar Di Kampus," Catatan Haikal, 2013.

${ }^{13}$ Novy Agrina, “Miris! Viral Video Anak SD Ciuman Sampai Guling-Guling Jadi Tontonan," popmama.com, 2018.

${ }^{14}$ Dony Indra Ramadhan, “UIN Bandung Akui Pemeran Video Mesum Merupakan Mahasiswanya," Detik News, 2018.
} 
janji Allah baik yang bersifat reward maupun punishment adalah bentuk kurang kuatnya akidah. Perilaku yang masih mengarah kepada perbuatan tidak baik adalah bentuk dari kurang kuatnya akhlak terpuji. Hal ini perlu ada perbaikan-perbaikan yang dilakukan demi terwujud harapan melahirkan ilmuan yang beriman, berilmu dan beramal Sholeh. Anak muda yang mengikuti kemajuan zaman tentu sangat paham dalam menjalani hidup sebagai masyarakat milenial. Namun jika hanya mengikuti gaya hidup milenial maka anak muda akan cenderung berbuat sesuka hati tanpa berpikir dampaknya. Oleh sebab itu era milenial harus diiringi oleh akhlak yang baik ${ }^{15}$.

Menyelesaikan masalah yang kompleks dan terstruktur memang tidak semudah membuat masalahnya, tetapi penanaman pola akidah akhlak ini akan menjadi solusi dan perbaikan secara perlahan-lahan yang insya Allah dengan izin Allah akan membawa kembali individu yang bermasalah kepada jalan yang sudah Allah arahkan. Pola ini perlu diterapkan bukan hanya pada satu bidang ilmu, atau seluruh bidang ilmu, melainkan menjadi nafas kehidupan keseharian dan dilakukan terus menerus. Pola yang penulis tawarkan ini berasal dari konsep magnet rezeki yang dirasa dapat mewakili dari segi konsep, langkah-langkan, lingkup, dan hasil yang diinginkan, serta semuanya berasal dari Allah berdasarkan wahyu dan dapat diamalkan secara perlahan. Ada tiga pola utama yang perlu ditanamkan untuk memperbaiki akidah dan akhlak: positive thinking, positive feeling, positive motivation ${ }^{16}$.

\section{Positifkan Pikiran}

Setiap pikiran adalah doa. Pola yang perlu ditanamkan pertama kali adalah memperbaiki pikiran. Apa-apa yang kita pikirkan adalah doa yang kita panjatkan kepada Allah. Pikiran mengeluarkan energi sekitar 6o.ooo pikiran setiap hari. Dan apa yang kita pikirkan akan masuk ke alam bawah sadar lalu memancar ke alam dan alam semesta akan bergerak mengikutinya atas kehendak sang pemilik alam ${ }^{17}$. Allah berfirman, "Berdoalah kepada-Ku, niscaya akan Kuperkenankan bagimu. Sesungguhnya orang-orang yang menyombongkan diri dari menyembah-Ku akan masuk neraka Jahanam dalam keadaan hina dina" (Q.S. Ghafir: 6o) ${ }^{18}$. Menjaga pikiran agar tetap positif bukan hal mudah, tetapi sangat-sangat wajib dilatih agar benar-benar terwujud. Untuk menjaga pikiran adalah dengan mengatur respons dari setiap fakta yang kita hadapi. Alam bawah sadar lebih mengenal fokus (dalam hal ini berupa predikat, bukan subjek atau objek) dari respons kita menghadapi sebuah kondisi. Contohnya adalah ketika seseorang mengalami kehilangan benda kesayangannya, alam bawah sadar tidak akan melihat apa yang hilang, siapa yang mengambil, tetapi bagaimana kita menyikapi kehilangan tersebut. Jika kita marah,

\footnotetext{
${ }^{15}$ Miftahul Fikri, Akhlak Milenial (Bogor: Arabasta Media, 2019).

${ }^{16}$ Nasrullah, Rahasia Magnet Rezeki, Menarik Rezeki Dahsyat Dengan Cara Allah (Jakarta: Elex Media Komputindo, 2016).

${ }^{17}$ Miftahul Fikri, Generasi Ajaib, Kekuatan Energi Pembentuk Generasi (Bogor: Arabasta Media, 2018).

${ }^{18}$ Subarkah et al., Syamil Quran, Al-Quran Dan Terjemah.
} 
berarti alam bawah sadar dalam pikiran kita merekam sebagai kemarahan dan ketidakrelaan.

Berprasangka tidak baik atau yang biasa dikenal suuzan adalah perilaku yang tercela dalam agama. Jika seseorang melakukan ini berarti dia sedang melakukan dosa, dan bersifat tidak positif. Ketidakbaikan ini dilakukan pada tataran pikiran. Dan walau hanya berada pada pikiran, tetap menimbulkan dosa. Pikiran tidak positif inilah yang akan merusak banyak hal, rusaknya hubungan kita dengan Allah, rusaknya tatanan rezeki, rusaknya komunikasi, dan sebagainya. Untuk menghilangkan suuzan tentu perlu membangun husnuzan. Husnuzan adalah berprasangka baik dan memberikan pahala bagi yang melakukannya. Membangun husnuzan ini bukanlah hal mudah, tatapi harus dipaksakan dan imbasnya adalah pikiran akan menjadi aman, karena yang ada di dalamnya adalah energi positif. Cara pertama, menanamkan husnudzan adalah dengan selalu berkata yang baikbaik atau yang bagus, atau bahkan kata "bagus" disetiap kondisi. Dalam hal ini, Nasrullah sebagai pencetus konsep ini selalu mengajarkan berkata "buagus itu" dalam setiap kondisi. Saat kehilangan benda yang kita cintai seperti sebelumnya, pikiran kita perlu dipaksakan untuk berprasangka baik. Prasangka baik kepada Allah, kepada lingkungan bahkan kepada orang yang mengamankan barang kita tanpa sepengetahuan. Saat kehilangan barang, kata yang diucapkan adalah "bagus itu". Latihan ini adalah latihan berat yang jika berhasil dilakukan akan membentuk pola ikhlas seketika dan rida atas keputusan Allah ${ }^{19}$.

Cara kedua, dengan meninggalkan semua konsumsi yang bersifat negatif. Televisi yang didominasi konten kurang positif sebaiknya ditinggalkan. Gosip, atau membicarakan orang lain terutama keburukannya, sebaiknya ditinggalkan, konten di media sosial yang kurang positif sebaiknya tidak perlu diikuti. Jika ini dilakukan akan mengamankan mata, telinga, mulut dan pikiran kita sekaligus dari perbuatan dosa. Cara ketiga, adalah dengan membiasakan berbicara dengan kata-kata yang positif. Kata "negatif" saja mengandung energi tidak positif dan mempengaruhi pikiran kita menjadi kurang positif. Memilih kata dengan kata yang lebih baik dan bersih, tidak berbicara kotor, jorok, kasar adalah bagian dari penanaman pola akidah dan akhlak sekaligus. Jika ini dilakukan akan lebih dominan mengucapkan kalimat Thayyibah dan lisan terjaga. Johansyah mengatakan bahwa poros utama dalam semua proses adalah menumbuhkan kesadaran terhadap setiap perilaku dan perbuatan yang dilakukan ${ }^{20}$, sehingga dengan kesadaran sendiri, seseorang akan langsung menerapkan secara otomatis. Abdullah juga berpendapat bahwa jika seseorang jauh dari agama maka pikiran akan kosong dan akan memikirkan hal tidak baik. Manusia yang jauh dari agama akan bertentangan dari fitrah manusia ${ }^{21}$.

\footnotetext{
${ }^{19}$ Nasrullah, Rahasia Magnet Rezeki, Menarik Rezeki Dahsyat Dengan Cara Allah.

${ }^{20}$ Johansyah, "Pendidikan Karakter Dalam Islam; Kajian Dari Aspek Metodologis," Jurnal Ilmiah Islam Futura XI, no. 1 (2011): 97.

${ }^{21}$ Aditya Abdullah, “Education Islam Di Era Millenial,” 2018, https://doi.org/10.31227/osf.io/72k9z.
} 


\section{Positifkan Perasaan}

Pola berikutnya yang ditanamkan untuk memperbaiki dan meningkatkan akidah akhlak generasi milenial adalah dengan mempositifkan perasaan. Perasaan ini memang sangat unik karena letak persisnya belum bisa terungkap. Tapi dengan mempositifkan perasaan ini akan membuat hidup lebih nyaman. Yang perlu dilakukan untuk mempositifkan perasaan adalah dengan menggunakan kekuatan bersyukur. Jika selama ini syukur dijadikan sebagai tujuan dalam pembelajaran, saat ini yang perlu dilakukan adalah menjadikan syukur sebagai kekuatan untuk menenangkan perasaan. Bersyukur kepada Allah atas apa yang sudah kita terima akan membuat diri menjadi pribadi yang tenang, tidak terlalu berambisi apalagi sampai menghalalkan segala cara. Jika kondisi yang dialami adalah ketidakbaikan, pada dasarnya Allah ingin memberikan yang baik dan terbaik, tetapi memang perlu ada ujian terlebih dahulu berupa ketidakbaikan. Ibarat permen dan bungkusnya, ketika seseorang mendapati permen yang tidak berbungkus, kita enggan memakannya karena terlihat kotor. Tetapi ketika kita mendapati permen yang masih di bungkus, tetap saja bungkusnya akan dibuang. Ini menandakan bahwa setiap individu menginginkan yang baik, bersih, higienis, tetapi itu semua perlu di bungkus dengan sesuatu yang tidak terlalu kita suka atau bahkan berbentuk musibah. Menerima semua keadaan dengan respons ikhlas di saat pertama kali diri mengalami ketidakbaikan adalah perintah agama. Bersabar adalah materi akhlak yang paling banyak ayatnya dalam Al-Quran. Bersabar di tumbukan pertama, di detik pertama adalah yang Allah inginkan ${ }^{22}$.

Ada sebuah alat yang Allah titipkan untuk membantu hambanya mempositifkan perasaan. Alat itu bernama Al-Quran. Al-Quran ini adalah pedoman hidup yang bukan hanya sekedar menjadi bacaan, tetapi memang dapat membentuk kondisi perasaan menjadi lebih positif. Salah satu metode yang menjadi bagian dari konsep ini dijuluki dengan istilah "Garpu Tala”. Ini digunakan untuk menemukan sebuah solusi dengan cara berdiskusi langsung dengan Allah melalui membuka ayat sekenanya dan ini diistilahkan sebagai "Istikharah bii AlQuran”. Allah akan menunjukkan ayat yang paling sesuai dengan kondisi hati yang sedang mencari. Allah berfirman bahwa "setiap habis kesulitan akan selalu ada kemudahan" ${ }^{23}$. Sering kali pikiran dan perasaan kita diselimuti rasa tidak tenang. Bayangan akan hal-hal yang dianggap akan terjadi selalu melintas. Ketakutan dan kekhawatiran ini menyelimuti dan membuat diri menjadi tidak positif perasaannya. Bagaikan diri yang sedang membayangkan menghisap jeruk nipis, walaupun hanya dalam bayangan, rasa asamnya tetap terasa. Ini pun sama, apa yang kita pikirkan seoral-olah terjadi padahal hanya bayangan.

Cara berikutnya untuk membuat perasaan tenang adalah meningkatkan ibadah wajib dan sunah serta fokus dalam mengerjakannya. Fokus dengan beribadah kepada Allah, mengutamakan ibadah dari aktivitas lain, apaligi hanya sekedar bercanda. Dalam konsep magnet rezeki disebut "Goa Keajaiban", seseorang

\footnotetext{
${ }^{22}$ Nasrullah, Rahasia Magnet Rezeki, Menarik Rezeki Dahsyat Dengan Cara Allah.

${ }^{23}$ Subarkah et al., Syamil Quran, Al-Quran Dan Terjemah.
} 
masuk kedalam kondisi seperti di dalam goa, hanya fokus beribadah saja, membaca al-Quran, berzikir, bersholawat, bermunajat secara fokus, mirip dengan kondisi beri'tikaf di masjid saat bulan Ramadhan. Hal ini dilakukan untuk meningkatkan keyakinan bahwa ketika seseorang lebih mementingkan Allah, Allah akan membantunya dalam segala urusan. Kondisi ketenangan hatilah yang diincar dari aktifitas ini. Contohnya ketika menginginkan sesuatu, sebelum melakukan ihtiar, perlu berada pada posisi ini, memasukan diri ke goa keajaiban mengharap kepada Allah dan biarkan Allah yang mendatangkan apa yang kita inginkan. Setelah memposisikan diri seperti ini, barulah kita berihtiar dengan tenang dan menikmati setiap prosesnya. Allah berfirman “... Barangsiapa bertakwa kepada Allah niscaya Dia akan mengadakan baginya jalan keluar; Dan memberinya rezeki dari arah yang tiada disangka-sangkanya. Dan barangsiapa yang bertawakkal kepada Allah niscaya Allah akan mencukupkan (keperluan)nya. Sesungguhnya Allah melaksanakan urusan yang (dikehendaki)Nya" (Q.S. Ath-Thalaq: 2-3) ${ }^{24}$. Urusan dunia adalah hal mudah bagi Allah, meletakan keyakinan secara penuh kepada Allah sudah menjadi krisis karena kita hanya mengandalkan rasio dan empiris saja, tidak meyakini adanya wahyu yang benar-benar dijamin. Ayat lain adalah "Apabila telah ditunaikan shalat, maka bertebaranlah kamu di muka bumi; dan carilah karunia Allah dan ingatlah Allah banyak-banyak supaya kamu beruntung" (Q.S. Al-Jumu'ah: 10) ${ }^{25}$. Ayat ini membenarkan bahwa mendahulukan ibadah daripada ikhtiar adalah perintah Allah.

\section{Positifkan Motivasi}

Pada bagian positif motivasi ini konsep magnet rezeki merujuk penelitian Danah Zohar dan Ian Marshall tentang Spiritual Meter, tetapi diserap ke dalam konsep ini dengan landasan wahyu. Spiritual meter ini membagi zona pada dua zona, zona takwa dan zona nafsu. Hal ini sesuai dengan ayat "maka Allah mengilhamkan kepada jiwa itu (jalan) kefasikan dan ketakwaannya” (Q.S. Asy-Syams: 8) ${ }^{26}$. Perbedaan zona takwa dan zona nafsu adalah pada energi yang dihasilkan. Zona takwa menghasilkan energi positif, dan zona nafsu menghasilkan energi negatif. Setiap zona memiliki 8 indikator, dan tiap indikator memiliki nilai energi berbeda. Zona takwa berada pada nilai energi +1 sampai +8 sedangkan zona nafsu berada pada nilai energi -1 sampai 8 .

\section{Zona Nafsu}

Penonjolan diri (-1). Penonjolan diri dalam Islam dikenal dengan nama ananiyah atau keakuan, yang merasa diri paling mampu, egois, memiliki harga diri tinggi, selalu ingin dipuji, riya. Semua aktivitasnya bertujuan untuk pujian manusia. Motivasi hidup hanya untuk pamer. Ibadah akan hilang seketika dan tidak akan pernah mendapatkan ketenangan jiwa; Kemarahan (-2), Emosi, atau berontak dari

\footnotetext{
${ }^{24}$ Subarkah et al.

${ }^{25}$ Subarkah et al.

${ }^{26}$ Subarkah et al.
} 
kondisi yang tidak disukai, dan kemarahan ini merusak kebahagiaan. Misalnya berteriak sambil marah terhadap sesuatu yang membuat tidak nyaman memiliki level energi negatif dua (-2). Dampak energinya lebih besar dari penonjolan diri, energi jiwa akan habis dan hati akan sangat tidak tenang dan mata akan melihat di sekeliling kita menjadi tidak baik. Bahkan orang di sekeliling akan merasa tidak nyaman dengan kemarahan. Kemarahan bukan hanya yang dimunculkan saja, tapi juga yang berada dalam hatinya, seperti dengki, dendam, iri hati, dongkol, jengkel, sombong (merendahkan orang lain dan menolak kebenaran); Keserakah (-3), serakah ini bisa dimaknai sebagai menginginkan sesuatu secara lebih dan tidak sesuai aturan, seperti prinsip ekonomi yang sering diterapkan, "modal sekecilkecilnya, untung sebesar-besarnya”. Pamrih juga bagian dari keserakahan yang merusak energi. Kemarahan yang bernilai -2 saja dapat merusak hubungan dengan sesama, apalagi serakah; Rasa takut (-4), ini dalam semua konteks takut keduniaan, misalnya takut mati, takut miskin, takut tidak bisa bayar hutang, takut debt collector, takut tersaingi, hilang barang-barang dan lain sebagainya yang menghilangkan kebahagiaan. Jika seseorang berada pada level ini, secara otomatis akan mengalami juga kondisi sebelumnya, orang yang takut biasanya akan lebih riya, sering marah, dan bahkan serakah karena merasa takut uangnya kurang, dan lain-lain ${ }^{27}$;

Keresahan (-5), orang kebanyakan energinya naik turun di +4 sampai -4 , jika sudah pada level ini berarti dirinya sudah berada pada level terpuruk. Biasanya orang yang berada pada level ini adalah orang yang melanggar aturan Allah seperti khianat, zalim, zina, mabuk-mabukan, durhaka pada orang tua, maling, korupsi, riba dan segala sesuatu yang jika dilakukan dan ketahuan orang lain akan membuat diri menjadi resah; Apati (-6), apatis atau putus asa biasanya sudah merasa tidak ada jalan lain untuk masalahnya. Satu-satunya jalan adalah tidak melanjutkan sama sekali. Misalnya pada orang suami istri, maka terjadilah perceraian. Ciri-ciri lain orang ada pada level ini adalah sering tergesa-gesa, tidak punya orientasi hidup, sering panik dan mulai menjauh dari kehidupan sosial; Malu dan Rasa bersalah (-7), biasanya dialami bagi orang yang merasa bersalahnya sangat besar. Hal ini terjadi pada orang yang kesalahan pada level -5nya sudah diketahui oleh orang banyak dan merasa terpuruk dengan itu. Kemudian seharusnya langkahnya adalah memperbaiki diri, tetapi malah sebaliknya, menutup diri; Depersonalisasi (-8), adalah kondisi seseorang yang sudah keluar dari fitrahnya sebagai manusia. Misalnya orang gila yang asyik dengan dunianya sendiri, orang yang sudah ketahuan berdosa tapi malah menyalahkan orang lain, bukan memperbaiki diri. Perilaku seks menyimpang seperti lesbi, gay, biseksual dan trans gender yang keluar dari fitrahnya, seharusnya laki-laki mencintai pasangan wanitanya yang sah dan sebaliknya, jika laki-laki menyukai laki-laki berarti sudah keluar dari sisi kemanusiaannya. Hal ini suka tidak suka berada pada level energi -8. Pemimpin yang zalim, apalagi sampai menganggap diri adalah Tuhan (seperti Firaun). Semua perbuatan yang ada pada zona nafsu ini adalah apa yang dilarang oleh Allah.

${ }^{27}$ Nasrullah, Rahasia Magnet Rezeki, Menarik Rezeki Dahsyat Dengan Cara Allah. 


\section{Aritmatika Energi}

Penjelasan tentang energi ini menunjukkan bahwa setiap perbuatan yang dilarang Allah memiliki nilai energi negatifnya. Jika digambarkan dalam hitungan matematika akan memberikan contoh yang lebih jelas. Misalnya ada seseorang yang sedang marah (-2), lalu dihadapi dengan marah juga (-2), maka anak membentuk energi negatif baru bernama rasa takut $(-4)$. Takut kalah, takut apa yang membuatnya marah benar-benar menjadi kenyataan dan lain sebagainya. Contoh lain, maling (-5) yang dimarahi oleh orang yang emosi (-2) akan membentuk energi negatif baru yaitu malu dan rasa bersalah yang besar $(-7)$ dan malah bukan membawa kepada perbaikan, tapi malah merusak. Begitu seterusnya jika perilaku negatif dihadapi dengan perilaku negatif. Untuk memperbaiki dan memberikan penanaman akidah akhlak yang tepat dan dapat diterima terutama pada individu atau kelompok yang berada pada era milenial adalah dengan energi positif yang berada pada zona takwa.

\section{Zona Takwa}

Eksplorasi (+1), berbeda dengan penonjolan diri, eksplorasi adalah menggali kemampuan diri. Hal ini lebih kepada menuntut ilmu. Menuntut ilmu di lembaga pendidikan seperti sekolah dan perguruan tinggi adalah bagian dari eksplorasi, selama menjaga niat yang sesungguhnya untuk menuntut ilmu akan mendapatkan pahala serta bernilai energi posiutif $(+1)$. Tedi Priyatna berpendapat bahwa menuntut ilmu pada era milenial ini perlu mengintegrasikan pembelajaran Pendidikan Agama Islam ke dalam seluruh aspek sistem pendidikan dengan inovasi mutakhir serta orientasinya adalah memperbaiki sikap dan perilaku beragama ${ }^{28}$; Kolaborasi/Sosialisasi (+2), membangun relasi melalui silaturahmi adalah bagian penting dari kolaborasi. Bersosialisasi dengan lingkungan dan masyarakat yang berakhlak dan berilmu akan membawa diri menuju energi positif. Irfan Ahmad Zain dan Mismit Husen berpendapat bahwa masyarakat berperan besar dalam pembentukan akhlak ${ }^{29}$. Anwar \& Salim juga berpendapat bahwa pendidikan karakter bangsa merupakan tanggung jawab bersama antara pemerintah, masyarakat, sekolah dan orang tua. ${ }^{30}$. Jika setiap individu memiliki energi positif, lalu menjadi orang tua yang mendidik anak, membentuk masyarakat, dan lingkungan sekolahnya positif, serta didukung oleh pemerintah yang berenergi positif maka akan terbangun tatanan masyarakat yang baik dan sesuai dengan harapan bangsa; Kekuatan dalam diri (+3), kejujuran adalah kekuatan dari dalam yang sangat besar. Misalnya mengembalikan barang yang ditemukan dan lain sebagainya. Kekuatan dari dalam ini lawan dari keserakahan yang mementingkan

\footnotetext{
${ }^{28}$ Tedi Priyatna, “Inovasi Pembelajaran PAI Di Sekolah Pada Era Disruptive Innovation," Jurnal Tatsqif 16, no. 1 (2018): 40.

${ }^{29}$ Irfan Ahmad Zain and Mismit Husen, “Dampak Pendidikan Masyarakat Pada Perubahan Akhlak Remaja," Atthulab: Islamic Religion Teaching and Learning Journal 4, no. 1 (2019): 5.

${ }^{30}$ Syaiful Anwar and Agus Salim, "Pendidikan Islam Dalam Membangun Karakter Bangsa Di Era Milenial," AlTadzkiyyah: Jurnal Pendidikan Islam 9, no. 2 (2018): 243,

https://doi.org/https://doi.org/10.24042/atjpi.v9i2.3628.
} 
diri sendiri. Membangkitkan kekuatan dari dalam ini akan meningkatkan nilai akidah kepada Allah dan akhlak. Penguasaan (+4), jika energi positif terus dilatih dan ditingkatkan, pada tahap ini saja seseorang sudah menjadi pribadi yang baik. Ciri-ciri penguasaan ini adalah ridho terhadap ketentuan Allah, apapun kondisi yang dialami, apapun kejadian yang ada didepan mata, tetap di terima dengan ikhlas. Ini juga merupakan bagian dari mengimani Qodho dan Qodar. Penerapan ini adalah penggabungan antara positive thinking yang aksimal dan positive feeling yang sempurna. Dan jika sudah menguasai ini, Allah akan memberikan kekuasaan di alam semesta seperti firman Allah "dan Allah telah berjanji kepada orang-orang yang beriman di antara kamu dan mengerjakan amal-amal yang saleh bahwa Dia sungguh-sungguh akan menjadikan mereka berkuasa di muka bumi, sebagaimana Dia telah menjadikan orang-orang sebelum mereka berkuasa, dan sungguh Dia akan meneguhkan bagi mereka agama yang telah diridhai-Nya untuk mereka, dan Dia benar-benar akan menukar (keadaan) mereka, sesudah mereka dalam ketakutan menjadi aman sentosa. Mereka tetap menyembahku-Ku dengan tiada mempersekutukan sesuatu apapun dengan Aku. Dan barangsiapa yang (tetap) kafir sesudah (janji) itu, maka mereka itulah orang-orang yang fasik" (Q.S. An-Nur: 55) ${ }^{31}$;

Generativitas (+5), pada tahap ini, seseorang akan jauh lebih sungguh-sungguh mengejar ridha Allah dan dengan penuh semangat. Selalu berhati-hati dalam hidup seperti berjalan di atas duri. Hati-hati menjaga pikiran dan perasaannya; Pengabdian dan cinta (+6), level berikutnya adalah sudah tidak peduli lagi dengan dirinya, karena dirinya sudah berada pada posisi positif yang tinggi. Pada level ini yang dipikirkan adalah orang lain dengan penuh pengabdian dan cinta. Misalnya seorang ibu yang rela memberikan segalanya demi anak. Orang di level ini akan selalu memberikan solusi dari masalah-masalah orang lain tanpa pamrih tentunya. Jiwa dunia (+7) dan Pencerahan (+8), berada pada level yang sangat-sangat tinggi. Orang yang berada pada level ini sudah tidak lagi mengharapkan apa-apa dari dunia. Semua yang dilakukan hanya mengharapkan balasan di akhirat saja. Tetapi ini adalah tahap terakhir setelah semua tahap terlewati ${ }^{32}$.

Membahagiakan orang lain adalah bentuk dari penerapan Akhlak, membahagiakan Allah adalah bentuk dari penerapan Akidah. Untuk menguatkan, perlu adanya kisah-kisah nyata yang terjadi sebagai gambaran bahwa konsep yang ditawarkan memang benar adanya. Adanya kisah-kisah nyata yang disampaikan dan terbukti tentu akan membuat keyakinan bertambah bahwa Allah memang maha kuasa dan maha segalanya. Menggunakan metode kisah terutama kisah yang berasal dari Al-Quran dapat membentuk karakter peserta didik ${ }^{33}$. Penguatan dengan testimoni orang-orang yang sudah mengamalkan konsep ini juga akan lebih membuktikan pola ini dapat diterapkan. Seluruh pola yang tertuang dalam artikel ini adalah pola yang dapat diterapkan pada mahasiswa di era milenial. Bukan hanya mereka, tetapi bisa diterapkan oleh seluruh umat muslim yang menginginkan kebaikan. Kelemahan dalam dunia Pendidikan Agama Islam adalah literatur yang

\footnotetext{
${ }^{31}$ Subarkah et al., Syamil Quran, Al-Quran Dan Terjemah.

${ }^{32}$ Nasrullah, Rahasia Magnet Rezeki, Menarik Rezeki Dahsyat Dengan Cara Allah.

${ }^{33}$ Mamik Rosita, “Membentuk Karakter Siswa Melalui Metode Kisah Qurani," Fitrah 2, no. 1 (2016): 70.
} 
kurang berkualitas. Suhadi berpendapat bahwa selama ini kualitas literatur terutama Pendidikan Agama Islam kurang berkualitas karena kurangnya referensi dan diskusi akademik ${ }^{34}$. Maka memperbaiki literatur dan menyusunnya agar mudah diaplikasikan adalah bagian yang tidak kalah penting untuk memperbaiki sisi keilmuan Pendidikan Agama Islam terutama akidah akhlak.

\section{Simpulan}

Berdasarkan pembahasan dalam artikel ini, dapat disimpulkan bahwa untuk menggambarkan pola dalam penanaman akidah akhlak berlandaskan wahyu memandu ilmu pada mahasiswa yang masuk kategori generasi milenial adalah dengan mempositifkan pikiran, mempositifkan perasaan dan mempositifkan motivasi. Penanaman positif pikiran dengan melatih diri untuk selalu berpikir positif, mempositifkan respons dar fakta yang terjadi, menjauhkan suuzan, mengganti kata negatif menjadi positif. Penanaman positif perasaan dengan melatih diri untuk bersyukur atas semua keadaan, menerima kenyataan, meyakini musibah yang datang pasti beriringan dengan nikmat yang besar, perbanyak membaca Al-Quran, dan fokus beribadah kepada Allah. Penanaman positif motivasi dengan melatih menghindarkan diri dari perbuatan yang masuk dalam zona nafsu yang memiliki energi negatif, dan melatih diri melakukan perbuatan yang masuk dalam zona takwa yang memiliki energi positif.

\section{DAFTAR PUSTAKA}

Abdullah, A. (2018). Education Islam di era millenial. https://doi.org/10.31227 /osf.io/72kgz

Aeni, A. N. (2014). Pendidikan karakter untuk siswa SD dalam perspektif Islam. Mimbar Sekolah Dasar, 1(1), 57. Retrieved from http://jurnal.upi.edu/mimbarsekolah-dasar/

Agrina, N. (2018). Miris! viral video anak SD ciuman sampai guling-guling jadi tontonan. Retrieved August 8, 2019, from popmama.com website: https://www.popmama.com/life/relationship/novyagrina/miris-viral-videoanak-sd-ciuman-sampai-guling-guling/full

Anwar, S., \& Salim, A. (2018). Pendidikan Islam dalam membangun karakter bangsa di era milenial. Al-Tadzkiyyah: Jurnal Pendidikan Islam, 9(2), 243. https://doi.org/https://doi.org/10.24042/atjpi.v9i2.3628

Fikri, M. (2018a). Generasi ajaib, kekuatan energi pembentuk generasi. Bogor: Arabasta Media.

Fikri, M. (2018b). Metode ilmiah ulama klasik. Jurnal Kajian Islam Modern, VI(11), 39.

Fikri, M. (2019). Akhlak Milenial. Bogor: Arabasta Media.

\footnotetext{
${ }^{34}$ Suhadi, "Menu Bacaan Pendidikan Agama Islam Di SMA Dan Perguruan Tinggi," in Literatur Keislaman Generasi Milenial, Transmisi, Aprporiasi, Kontestasi (Yogyakarta: Pascasarjana UIN Sunan Kalijaga Press, 2018), 61.
} 
Hadhari. (2016). Tela'ah atas keteladanan Rasulullah saw dalam mendidik anak. Sumbula: Jurnal Studi Keagamaan, Sosial Dan Budaya, 1(1), 161. Retrieved from http://ejournal.kopertais4.or.id/mataraman/index.php/sumbula/article/view/22 73

Haikal. (2013). Komentar IAIN/UIN tentang dzikir anjing-hu akbar di kampus. Retrieved August 8, 2019, from Catatan Haikal website: http://www.catatanhaikal.com/2013/o9/iainuin-sangkal-terjadi-penyusupananti.html

Harianto, S. (2018, November 6). Menggelikan, puluhan peserta tes CPNS di Madiun ketahuan bawa jimat. Retrieved August 8, 2019, from Detik News website: https://news.detik.com/berita-jawa-timur/d-4289952/menggelikan-puluhanpeserta-tes-cpns-di-madiun-ketahuan-bawa-jimat

Johansyah. (2011). Pendidikan karakter dalam Islam; kajian dari aspek metodologis. Jurnal Ilmiah Islam Futura, XI(1), 97. Retrieved from https://jurnal.arraniry.ac.id/index.php/islamfutura/article/view/63

M Sobandi. (2016). Wahyu memandu ilmu dan implementasinya untuk menggapai the second golden ages of muslim. In Buku 2 trilogi wahyu memandu ilmu (pp. 158-159). Bandung: Wahyu Memandu Ilmu.

Nasrullah. (2016). Rahasia magnet rezeki, menarik rezeki dahsyat dengan cara Allah. Jakarta: Elex Media Komputindo.

Nata, A. (2018). Pendidikan Islam di era milenial. Conciencia, 18(1), 10. https://doi.org/https://doi.org/10.19109/conciencia.v18i1.2436

Priyatna, T. (2018). Inovasi pembelajaran PAI di sekolah pada era disruptive innovation. Jurnal Tatsqif, 16(1), 40. Retrieved from http://journal.uinmataram.ac.id/index.php/tatsqif/article/view/158

Ramadhan, D. I. (2018). UIN Bandung akui pemeran video mesum merupakan mahasiswanya. Retrieved August 8, 2019, from Detik News website: https://news.detik.com/berita-jawa-barat/d-4237216/uin-bandung-akuipemeran-video-mesum-merupakan-mahasiswanya

Rosita, M. (2016). Membentuk karakter siswa melalui metode kisah Qurani. Fitrah, 2(1), 70 .

Ruhenda, \& Anggraeni, D. (2018). Penanaman nilai agama Islam dalam keluarga dengan akhlak remaja. Jurnal Obor Penmas, 1(1), 36. Retrieved from http://ejournal.uika-bogor.ac.id/index.php/OBORPENMAS/article/view/1480

Subarkah, A., Tohari, H., Kafiyanto, M., Rahadian, H. F., \& Saefudin. (2012). Syamil Quran, Al-Quran dan terjemah. Bandung: Syamil Quran.

Suhadi. (2018). Menu bacaan pendidikan agama Islam di SMA dan perguruan tinggi. In Literatur keislaman generasi milenial, transmisi, aprporiasi, kontestasi (p. 61). Yogyakarta: Pascasarjana UIN Sunan Kalijaga Press.

Suhartini, A. (2016). Strategi penerapan wahyu memandu ilmu dalam bidang ilmu pendidikan agama Islam di UIN Sunan Gunung Djati Bandung. In Buku 2 trilogi wahyu memandu ilmu (p. 95). Bandung: Wahyu Memandu Ilmu.

WMI, T. P. K. (2016). Buku 1 Trilogi wahyu memandu ilmu. In Trilogi wahyu memandu ilmu (pp. 14-15). Bandung: Konsorsium Wahyu Memandu Ilmu. 
Yunus, U. K., \& Dewi, K. (2018). Streategi guru akidah akhlak dalam menanamkan karakter islami peserta didik MTs. GUPPI Samata Gowa. Jurnal Isnfirasi Pendidikan, VII(1), 93. Retrieved from http://journal.uinalauddin.ac.id/index.php/Inspirasi-Pendidikan/article/view/4936

Zain, I. A., \& Husen, M. (2019). Dampak pendidikan masyarakat pada perubahan akhlak remaja. Atthulab: Islamic Religion Teaching and Learning Journal, 4(1), 5. 